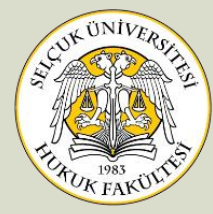

\title{
THE IMPACT OF THE EUROPEAN COURT OF HUMAN RIGHTS OVER LOCAL NORMS: THE CASE OF TURKEY ${ }^{1}$
}

\author{
Arş. Gör. Murat POYRAZ*
}

\begin{abstract}
The article aims at exploring the impact of the European Court of Human Rights on the local norms of Turkey, a topic that has been understudied, given its burgeoning significance. The Court is institutionally able to exercise such influence on the state parties, as it is entitled to have final jurisdiction over member states concerning compliance with the Convention and its content. Moreover, the Convention itself also necessitates contracting states to conform to the final judgment of the Court and to take sufficient measures, including changes in the local norms to guarantee that the Convention's rights and freedoms are protected. However, the influence of the Court on domestic norms of a national law needs to be elaborated since it remains silent concerning its impact on local norms. Hence, this article chooses Turkey as a case study to study the impact of the Court over local norms.
\end{abstract}

\section{Key Words}

Turkey • The European Convention on Human Rights • Local Norms • The European Court of Human Rights • The Court's Impact

1 The study is based on the author's master thesis.

* Araştırma Görevlisi, Recep Tayyip Erdoğan Üniversitesi İktisadi ve İdari Bilimler Fakültesi, Uluslararası İlişkiler Bölümü, Rize, Türkiye| Ress. Asst., Recep Tayyip Erdogan University, Faculty of Economics and Administrative Sciences, Department of International Relations, Rize, Turkey.

$\Xi$ murat.poyraz@erdogan.edu.tr • ORCID 0000-0002-8352-0241

Atıf Şekli | Cite As: POYRAZ Murat, “The Impact of the European Court of Human Rights over Local Norms: The Case of Turkey", SÜHFD., C. 29, S. 4, 2021, s. 3299-3323.

İntihal | Plagiarism: Bu makale intihal programında taranmış ve en az iki hakem incelemesinden geçmiştir. I This article has been scanned via a plagiarism software and reviewed by at least two referees. 


\section{AVRUPA İNSAN HAKLARI MAHKEMESI'NINN YEREL NORMLAR ÜZERINE ETKİSİ: TÜRKIYYE ÖRNEĞİ}

Öz

Bu makalenin amacı, Avrupa İnsan Hakları Mahkemesi'nin Türkiye'nin önemi gittikçe artan fakat üzerinde henüz yeterince çalışmamış bir konu olan iç hukuk normları üzerine etkisini tahlil etmektir. Kuramsal olarak, Mahkeme Sözleşmeye uyumdan ve Sözleşme'nin içeriği hususunda üye devletler üzerine nihai yarg1 yetkisine sahip olduğundan Mahkeme muhatap devletler üzerinde böyle bir etki gösterebilir. Ayrıca, Sözleşme'nin bizatihi kendisi de taraf devletlerin Mahkeme'nin nihai kararına uymasını ve Sözleşme'de yer alan hak ve özgürlükleri güvence altına almak için yerel normlarda değişiklikler de dahil olmak üzere gerekli önlemleri almasını gerektirmektedir. Ancak, Mahkeme yerel normlar üzerine olan etkisi konusunda sessiz kaldığı için ulusal hukukun iç normları üzerindeki etkisinin ayrıntılı olarak ele alınması gerekmektedir. Bu nedenle, bu makale Mahkeme'nin yerel normlar üzerine olan etkisini analiz etmek için Türkiye'yi örnek olarak seçmiştir.

\section{Anahtar Kelimeler}

Türkiye • Avrupa İnsan Hakları Sözleşmesi • Yerel Normlar • Avrupa İnsan Hakları Mahkemesi • Mahkeme'nin Etkisi

\section{INTRODUCTION}

There is a general agreement ${ }^{2}$ that today's most potent regional human rights regime is the regime of The European Convention on Human Rights $^{3}$. The Convention that aims at maintaining and promoting

2 DZEHTSIAROU, Kanstantsin and Vassilis P. TZEVELEKOS, “The Conscience of Europe that Landed in Strasbourg: A Circle of Life of the European Court of Human Rights"', Volume 1, No 2, 2020, p. 1.

3 On 4 November 1950, the Convention for the Protection of Human Rights and Fundamental Freedoms that was to be predominantly known later as either 'the European Convention' or 'the European Convention on Human Rights' was signed by the foreign minister of the member states at the time, and it became fully operational in September 1953, with the adequate number of signatory parties to ratify and give effect to it in their municipal law. All member states of the Council are a side to it owing to the Statute of the Council, which makes the High Contracting States to adopt it. For further information, please see the details, BOND, Martyn, An Introduction to the European Convention on Human Rights, Strasburg, Council of Europe Publishing, 2018, p. 5-63. 
democratic principles sets up an essential list of rights and freedoms to which all signatory states ${ }^{4}$ are bound and have been improved through Additional Protocols in terms of its scope and capabilities. To safeguard the Convention's established rights and freedoms and to provide justice in individual and interstate cases, the European Court of Human Rights was formed in the year 1959 as a judicial entity of the Council of Europe by the contracting parties. ${ }^{5}$ State parties, apart from that, in this unique system, are under many obligations springing from the Convention, such as the obligation to "undertake to abide by the final judgment of the Court in any case to which they are parties" .6 The respondent States, in this connection, aim to take either/both individual or/and general measures in an effort to provide redress to the applicant who suffered from actual or/and legal practices of his/her home country and to prevent new violations that/those found by the Court and/or bring the ongoing violations to an end. In this regard, general measures could do with local norms in the respondent State's legal system.

Hence, the influence of the Court needs to be addressed in detail, as the Court is silent on its effect on local norms. In this vein, the core research question arises as to how the Court have an effect on local legal norms in Turkey- a country that ranks as second in respect of pending applications assigned to a judicial formation as of 31 August 20217. The manuscript is accordingly divided into two sections. In order to

$4 \quad$ To see member states, please see <https://www.coe.int/en/web/portal/47-membersstates $>$ (accessed, on 25 July, 2021).

5 The Council of Europe is an intergovernmental organization established by the ten founding countries and the six founding fathers, who were also leading pioneers in setting up the two European community, namely the European Coal and Steel Community and European Economic Community. For a good account on the historical analysis of the agency, please see WASSENBERG, Birte, History of the Council of Europe, Strasbourg, Council of Europe Publishing, 2013, p. 1-32.

6 "The Convention for the Protection of Human Rights and Fundamental Freedoms", $<$ https://www.echr.coe.int/documents/convention_eng.pdf $>$ (accessed, on 25 July, 2021), (hereinafter, the Convention).

7 As of 31 August 2021, the total number of pending applications before the Court reached at 70,550, 14,951 of which were lodged against Turkey, please see <https://www.echr.coe.int/Documents/Stats_pending_month_2021_BIL.PDF> (accessed, on 25 July, 2021). 
understand the Court's influence on local norms, it is necessary to grasp the relationship between the Court and the Convention regarding local norms. What does it imply? How important is it? The first section of the article is centrally concerned with these questions. The last section investigates the impact of the Court over local norms by concentrating on Turkey. In this section, firstly, the question of whether or not the composition of Turkish national law in relation to international law has an influence on the transformation of local norms in its legal system will be elucidated. Later, the Court's impact on local norms in Turkey is grouped into three subheadings so as to grasp better its influence.

\section{THE EUROPEAN COURT OF HUMAN RIGHTS AND LO- CAL NORMS}

Before examining the very core of this section, it is essential to underline at the outset that the Court's impact upon national law is contingent upon the European Convention on Human Rights together with the Additional Protocols, as the Strasbourg Court has the authority to deliver judgments based on the interpretation and application of the Convention and the Protocols. Therefore, it seems to be apparent that the impact of the European Court does not automatically emerge. Instead, the Court should find the Parties to the Convention to be in an act of infringe contrary to rights and freedoms enshrined in it. In addition to that dimension, the European Convention did bring into existence the Strasburg Court, and the Court has exclusive authority over the legal interpretation of the Convention's rights and freedoms. ${ }^{8}$ In that sense, this is to say that any legal issue regarding local norms makes it necessary to look into the European Convention. In this regard, state parties are expected to uphold and safeguard human rights and fundamental freedoms within their sovereignty, according to Article $1^{9}$. This provision requires member states to observe the specified rights and freedoms to any person, group of people

The Convention, art. 32.

9 In the case N.D. and N.T. v. Spain, the Court indicated that Article 1 draws no distinction regarding rules or measures and does not exempt any element of a member state's jurisdiction from the Convention's scrutiny. N.D. and N.T. v. Spain [GC], nos. 8675/15 and 8697/15, 13 February 2020, para. 102-103. 
and non-governmental organizations within their own jurisdiction. ${ }^{10}$ In the Court's assessment ${ }^{11}$, it follows, inter alia, that Contracting State's commitment is limited to securing the stated rights and freedoms within its jurisdiction, indicating chiefly territorial jurisdiction of a state's competence. As pointed out evidently above, it is primarily state entities that are responsible for the preservation of rights and freedoms enunciated in the Convention. Consequentially, if any provision of national law of a state entity contradicts with the Convention, changes in local norms become an obligation.

In the light of Article $17^{12}$ prohibiting the abuse of rights and freedoms, the Convention, on the other hand, does not grant state parties to the "[r]ight to engage in any activity or perform any act aimed at the destruction of any of the rights and freedoms set forth herein or at their limitation to a greater extent that is provided for in the Convention"13. Thus, any changes in local norms should be in conformity with this provision of the Convention. For that reason, if the Court concludes that a state party has violated the Convention and thus demands changes in the national norms of the defendant State, measures, regardless of individual or/and general, to be adopted by the respondent State should be in tune with the final decision.

At this point, the nature of the judgments of the Court is another point to be discussed. The character of judgments of the Court is considered to be a final - the principle of the finality of judgments - and binding over states which are party to the Convention. According to Article 46, a

10 The jurisdiction of the Strasburg Court today covers more than Europe's 830 million citizens to complain against one of the 47 signatory states for violating their human rights laid down in the convention, please see $<$ https://www.coe.int/en/web/impactconvention-human-rights/how-it-works\#: :text=The\%20human $\% 20$ rights $\% 20$ convention $\% 20$ protects,human $\% 20$ rights $\% 20$ and $\% 20$ basic $\% 20$ freedom $>$ (accessed, on 18 August, 2021).

11 Georgia v. Russia (II) [GC], no. 38263/08, 21 January 2021, para. 81.

12 Under the Court's findings in Kastmakhunov and Saybatalov, the main aim of Article 17 of the Convention is to hinder individuals or groups or non-governmental organizations with totalitarian goals from taking advantage of the Convention for their own purposes. Kastmakhunov and Saybatalov v. Russia [First Section], nos. 26261/05 and 26377/06, 14 March 2013, para. 103-104. 
final judgment also necessitates its execution under the supervision of the Committee of Ministers. The Court states about the execution of a judgment that it is essentially member states to select the means to be employed in their national law to comply with its obligation under the Convention. These means must be coherent with the Court's conclusion and spirit. Nonetheless, on the condition that such measures are consistent with the Court's conclusion, states that violate an article of the Convention are free to pick up means to discharge their obligation under Article 46 of the Convention, for the judgments of the European Court are primarily declaratory ${ }^{14}$, meaning that the judgments of the Court cannot by itself erase the actual or legal violation contrary to the Convention. ${ }^{15}$ Hence, the Court, in the case Soering $v$. the United Kingdom ${ }^{16}$, rejected the applicant's request for legal redress - a request that gives instructions to the defendant State to execute the Court's conclusions in the judgment concerned in its domestic legal order. The Court considers that there is no such a right in the Convention and that whether measures taken by the respondent State are sufficient for the compliance with the final decision, falls within the remit of the role and functions of the Committee of Ministers.

In this connection, it should also be stressed here that, under certain special circumstances, the Court might advise a respondent State on the types of measures ${ }^{17}$ that might be adopted to end the condition that has resulted in a violation finding since "the very nature of the violation found was such as to leave no real choice between measures capable of remedying $i^{\prime \prime 18}$. In this regard, the judgment of the Court may indicate

14 Öcalan v. Turkey [GC], no. 46221/99, 12 May 2005, para. 207-210

15 Marckx v. Belgium [Plenary], no. 6833/74, 13 June 1979, para. 58

16 Soering v. The United Kingdom [Plenary], no. 14038/88, 07 June 1989, para. 125-127.

17 ISSAEVA, Maria, Irina SERGEEVA and Maria SUCHKOVA, "Enforcement of the Judgments of the European Court of Human Rights in Russia", International Journal on Human Rights, Volume 8, No 15, 2011, p. 68-71. On the further information on how the Court indicates specific individual measures, see Assanidze v. Georgia [GC], no. 71503/01, 8 April 2004, para. 208; Del Rio Prada v. Spain [GC], no. 42750/09, 21 October 2013, para. 149; Aleksanyan v. Russia [First Section], no. 46468/06, 22 December 2008, para. 240.

18 Gasangusenov v. Russia [Third Section], no. 78019/17, 30 March 2021, para. 100. 
changes in the local norms contrary to the Convention as a particular type of remedying the injured party. Nevertheless, this does not mean that measures, with the aim of providing redress to the suffering applicant, are limited to changes in national norms. In addition to this, there are also a variety of measures: reopening of domestic proceedings, just satisfaction, restitution, and legislative reforms, to name some of them. In this vein, as is discussed above, the Court indicates a particular type of remedying in the final judgment. In addition to that, the respondent State also freely chose to bring an end to the infringement found by the Court. This dimension is somehow linked to the margin of appreciation - a doctrine that allows state parties, which have breached the Convention, to a degree of flexibility in order to fulfil their obligations. ${ }^{19}$

It is also important to emphasize that the respondent State provides redress to the injured part through individual or/and, if needed, general measures. The former, on the one hand, relates the applicants. There are two aspects to the obligation to take individual measures and provide redress to the applicant. The first is to pay an amount of money awarded by the judgment of the Court. However, the consequences suffered by the applicant are not generally sufficiently remedied by the Court's decision to pay a justification. It is here that a further measure can be needed so as to achieve as much as possible restitutio in integrum. These measure ${ }^{20}$ may include the destruction of false information violating the right to privacy, the reopening of civil proceedings, or the cancellation of a deportation order which leaves the applicant to be subjected to torture or ill-treatment. The latter, on the contrary, concerns measures aiming to hinder identical violations at the national level. Hinging upon the circumstances, the fundamental obligation of taking general measures may call for actions ${ }^{21}$ involving, for example, the refurbishing of a prison, the improvement of

19 İNCEOĞLU, Sibel, “Hak ve Özgürlükleri Sınırlama ve Güvence Rejimi”, within İnsan Hakları Avrupa Sözleşmesi ve Anayasa: Anayasa Mahkemesine Bireysel Başvuru Kapsamında Bir İnceleme, ed. Sibel İnceoğlu, Istanbul, Beta Yayınları, 2013, p. 32.

20 For more individual measures, please see <https://www.coe.int/en/web/humanrights-convention/individual-measures $>$ (accessed, 11 August, 2021).

21 For more general measures, please see $<$ https:/www.coe.int/en/web/human-rightsconvention/general-measures $>$ (accessed, 11 August, 2021). 
detention conditions for persons awaiting deportation, the decriminalization of homosexual acts, the change of domestic case-law or the introduction of an effective compensation system.22 The defendant State, to erase the consequences and comply with its undertaking of taking measures, prepares an action plan that includes steps to be taken at the national level, as well as an action report, which features whether steps in the action report are executed. Following this, the Committee of Minister ends the supervision process by issuing a final resolution regarding whether steps taken are sufficient for the elimination of the damage ${ }^{23}$.

Overall, these issues pointed out above are legal obligations ${ }^{24}$ of the Convention Parties. Thus, a state party violating its obligation should take all necessary steps through which to comply with the decision of the Court since the contracting states have the obligation to abide by the binding decision of the Court ${ }^{25}$, which also points to the superiority of the final judgments of the Court on national laws. Hence, conformity to the judgment becomes a must.

\section{PRACTICE IN TURKEY}

The very scope of this section is to delve deeper into the question of how the European Court influences the transformation of legal norms in Turkey. Before digging into the question, firstly, it is worth noting that one may argue that the issue of if the composition of the Turkish legal system towards international law may affect the content of its local norms. Turkey willingly joined the European Convention as a Contracting Party on 18 May 1954, later ratifying and putting into force the Convention

22 ABDELGAWAD, Elisabeth Lambert, The Execution of Judgments of the European Court of Human Rights, Strasbourg, Council of Europe Publishing, 2008, p. 27-31.

23 The Convention, art. 46.

24 In the light of the International Court of Justice, as well as Article 27 of Vienna Convention on the Law of Treaties, a state party may not use elements of its municipal legal order as an excuse for its inability to comply with a provision or provisions of international treaty it ratified and entered into force with other entities that are capable of concluding a treaty. This obligation deriving from international customary law is a sine qua non in state responsibility under international law. MOORHEAD, Timothy, "European Union Law as International Law", European Journal of Legal Studies, Volume 5, No 1, 2012, p. 126-128.

25 The Convention, art. 46. 
concerned. Later on, in 1987, both the competence of the European Commission of Human Rights and the right of individual petition for violation performed by Turkish authorities within its territory where the Turkish Constitution is applicable were acknowledged by Turkey. On 22 January 1990, nearly three years after the recognition of the right to the individual application, Turkey also recognized the mandatory jurisdiction of the Court, removing the last obstacle to the full operating of the human rights system. ${ }^{26}$

Concordantly, the determinant of Turkey's relationship with international law is its constitution ${ }^{27}$ adopted in 1982 through a referendum, as in many other countries. Moreover, yet, it remains to be mentioned that state parties under international law are bound by certain responsibilities concerning the composition of a legal system. For instance, according to Article 27 of the Vienna Convention on the Law of Treaties of 1969, "a party may not invoke the provisions of its internal law as justification for its failure to perform a treaty" 28 - an article that is considered as part of international customary law. Together with the principle of pacta sun servanda, therefore, any provision in any legal system be comply with this provision of international law. In this vein, the Constitution of 1982 does not directly address the question of how its relations with international law are regulated. However, the Constitution specifies how international treaties to which Turkey signed and ratified ${ }^{29}$ would be applied in Turkish

26 SALIHPAŞAOĞLU, Yaşar, “Avrupa İnsan Hakları Mahkemesi ve Türkiye: Bazı Rakamlar ve Gerçekler", Gazi Üniversitesi Hukuk Fakültesi Dergisi, Volume 8, No $1-2,2009$, p. 266. For the reservations and declarations of Turkey for the Convention, please see" <https://www.coe.int/en/web/conventions/full-list?module=declarationsby-treaty\&numSte $=005 \&$ codeNature $=1 \&$ codePays $=$ TUR $>$ (accessed, on 24 August, 2021).

27 APAYDIN, Deniz Tekin, “Monizm-Dualizm İkileminde Türk Hukuk Sistemi: Uluslararası Hukuka Bakış Üzerine Doktrinel Uzlaşmazlığın Nedenleri ve $A B$ Hukuku Işığında Bir Değerlendirme", İnönü Üniversitesi Hukuk Fakültesi Dergisi, Volume 9, No 1, 2018, p. 549.

28 Vienna Convention on the Law of Treaties, art. 27.

29 Over the ratification of international treaties, Article 90 of the Constitution stipulates that international treaties concluded with foreign states are subjected to a legal process by which they enter into force through a law to be adopted by the Turkish Assembly, which is followed by the rafitication and promulgation of international treaties by Turkish President respectively, domestoc courts in Turkey begin 
domestic law in terms of some issues. ${ }^{30}$ Article 90 of the Constitution provides that "international agreements duly put into effect have the force of law....In the case of a conflict between international agreements, duly put into effect, concerning fundamental rights and freedoms and the laws due to differences in provisions on the same matter, the provisions of international agreements shall prevail." 31 This provision has been long debated by Turkish scholars and researchers, leading to two dissimilar approaches $^{32}$ on how it will be interpreted in such a case. On this point, Aybay argues that the wording 'prevail' ought not to be understood in terms of priority of international treaties concerned, even though the Constitution does evidently determine the hierarchical position of the

enforcing them, thus becoming effective in Turkish municipal law. This provision also includes exceptional circumstance where the provision cannot be applied. The same provision stipulates that agreements governing economic, commercial or techincal dimension for a periof of no more than one year may be entered into force if they do not feature provisions regarding financial commitment for Turkey and do not bring regulations on the status of individuals or the propreitary rights of Turks abroad. Turkey's national assembly must be informed of these agreements within a period of two months following their proclamation. For the other exceptional circumstances, see QORABOYEV, Ikboljin and Emre Turkut, "Turkey", within Duelling for Supremacy: International Law vs. National Fundemental Principles, ed. Fulvio Maria Palombino, Cambridge, Cambridge University Press, 2019, p. 337-339.

30 These legal issues are strictly limited. Besides the ratification of treaties, the Constitution, concerning its relations with international law, also adresses suspension of the exercise of fundemental rights and freedoms, status of aliens, right and duty of education, and decleration of state of war and authorization to deploy the armed forces, see PAZARCI, Hüseyin, Uluslararası Hukuk, Ankara,Turhankitapevi, 2009, p. 23-24.

31 The Constitution of the Republic of Turkey, art. 90, https://global.tbmm.gov.tr/docs/constitution_en.pdf, (accessed, on 21 November, 2021).

32 For more information on the debate, please see SAĞLAM, Fazıl, "Avrupa İnsan Hakları Mahkemesi'nin Türkiye' de Kapatılan Partilere İlişkin Kararlarının Partiler Hukukuna Etkisi", p. 90-95, https://ayam.anayasa.gov.tr/media/6307/fazil_saglam.pdf (accessed, on 21 November, 2021); GÖZTEPE, Ece, “Avrupa İnsan Hakları Mahkemesi Kararlarının İç Hukuka Etkisi Sorunu: Federal Almanya Anayasa Mahkemesi'nin İki Kararının Bir Değerlendirilmesi", within Erdoğan Teziç'e Armağan, Istanbul, Galatasaray Üniversitesi Yayınları, 2007, p. 426-429; BİLGİN, Ahmet Burak, “Avrupa İnsan Hakları Sözleşmesinin İç Hukuktaki Yeri”, Marmara Üniversitesi Hukuk Fakültesi Hukuk Araştırmaları Dergisi, Volume 22, No 1, 2016, p. 90-113; CAN, Hacı, "Türk Hukuk Düzeninin Milletlerarası Hukuka Açıklığı", Yasama Dergisi, Volume 12, No 5, 2009, p. 14-58. 
international agreements in the legal system of Turkey by stating "have the force of law". ${ }^{33}$ Nevertheless, given the fact that the Convention concerns the human rights of individuals, groups of people and non-governmental organizations, in case of a conflict between international treaties regarding human rights and Turkish national law, the principle "lex posterior derogat priori" is applied. Nonetheless, it remains to be stressed here that, according to Article 53 of the Convention, the provisions of the Convention do not limit or derogate from any of the human rights and freedoms "which may be ensured under the laws of any High Contracting Party or under any other agreement to which it is a party". ${ }^{34}$ Therefore, the aforementioned principle must be considered within the context of Article 53.

Consequently, considering both international law and national law, Turkey voluntarily accepted the Court's jurisdiction, meaning that, considering international customary law, it should observe its obligations and cannot use a provision in its municipal legal system to justify its inability to comply with its obligations stemming from the Convention. Therefore, the relationship of Turkish national law with international law is not an obstacle to its obligation to take necessary measures, including norm changes, to provide redress to the applicant.

Turning to the effect of the Court's judgments over local norms, the respondent Governments, on the one hand, can make norm changes in their domestic laws as a result of the final judgment that indicates the necessity of norm changes in its legal system. The relevant Governments, on the other, can make norm changes in their domestic law through their own free will after the final judgment that finds a breach of the Convention's Article or Articles, as noted earlier. In this connection, changes in local norms can be examined under three subheadings within the context of Turkey: the abolition of norms, the amendments of norms, and passing new norms, all of which will be analysed in detail in the following titles.

\subsection{The Abolition of Norms}

33 AYBAY, Rona, “Uluslararası Antlaşmaların Türk Hukukundaki Yeri”, Türkiye Barolar Birliği Dergisi, Volume 70, 2007, p. 204-205.

34 The Convention, art. 53. 
National norms in the respondent State occasionally fall foul with the final judgment of the Court. At this stage, the respondent State can choose to abolish local norms in its legal system as part of the obligation. To illustrate, Turkey violated the applicant's right of access to municipal court in the cases ${ }^{35}$ of Eşim v. Turkey and Sefer Yılmaz and Meryem Yılmaz $v$. Turkey. The violation in both cases stemmed from the Supreme Military Administrative Court's (the SMAC) assessment of the expiration of the time limit. In the former case ${ }^{36}$, in 1990, the defendant was injured while serving in the army. The applicant alleged that he had a bullet in the head while performing his service - a fact that was not identified at that time but later was revealed as a consequence of a medical examination in 2007 which led him to know that the removal of the bullet would put his life at jeopardy. Thus, the applicant subsequently claimed for compensation request, which was declined by the SMAC due to the five-year time limit. The Court, in this case, noted that the right of action must have been performed by the SMAC in the personal injury compensation cases, as the plaintiff was able to assess the damage after the medical examination.

On the latter case ${ }^{37}$, the applicants' son, Muhammed Y1lmaz, died at the age of 21 while performing his compulsory military service in 2008 in Bingöl. Two years later, his parents filed a claim for both pecuniary and non-pecuniary damage on account of the absence of evidence in the investigation file to prove that their son had committed suicide. The SMAC dismissed the applicants' request, as they had not followed the one-year time limit for the damages concerned. However, the Court was of the view that the term of litigation should have been started when the applicants became aware of the administration's potential negligence. Therefore, it seems to be the fact that the SMAC in both cases strictly applied Article 43, which regulates full remedy action, of Law no 1602 and that the violation is a result of the local norm concerned. According to the

35 "Communication from Turkey concerning the Esim group of cases v. Turkey", $<$ https://hudoc.exec.coe.int/eng\#\{\%22tabview\%22:[\%22document \%22],\%22EXECIdentifier\%22:[\%22DH-DD(2019)250E\%22]]> (accessed, on 22 August, 2021).

36 Esim v. Turkey [Second Section], no. 59601/09, 17 September 2013, para. 4-27.

37 Sefer Yılmaz ve Meryem Yılmaz / Türkiye [Second Section], no. 611/12, 17 November 2015, para. 4-107. 
action report ${ }^{38}$ submitted by Turkey for these two cases, the constitutional amendments - the Law on Amendment of the Constitution of the Republic of Turkey ${ }^{39}$ - in 2017 abrogated the whole military jurisdiction, including the SMAC and hence abolished Article 43 of the Law no 1602. In place of this court, the civil administrative courts are entitled to settle the issues concerning the military administration. The Committee of Ministers, in pursuance of the amendment, closed the cases owing to the fact that their approach for the issues under military administration is in line with the Court's findings.

In the action report for the above-mentioned cases, the legal practice - the SMAC - and norms regulating it were totally removed in the Turkish legal order with the introduction of the said amendment. Nevertheless, it is to be noted that the violation concerned was emanating from Article 43, meaning that the amendment just for this provision was likely possible, complying it with the findings of the Court. Thus, the attempt to remove the whole military jurisdiction in Turkey through the constitutional amendment brought with it conformity with the Court's judgment. Yet, the question arises as to whether or not the removal of the whole military jurisdiction was necessary. At this point, Gözler ${ }^{40}$ argues that military courts in Turkey did not meet principles put forward by the Court, such as lawfulness, independence, and impartiality. Therefore, the constitutional amendments came into line with the Court's findings in general in that sense. Moreover, the abolition of local norms, as in this case, created a different legal practice, i.e., civil administrative courts. These courts do need a legal basis in order to fulfil their duties. In other words, the abolition of the local norm in question also led to the emergence of a new norm in the Turkish legal system.

38 "Communication from Turkey concerning the Esim group of cases v. Turkey", $<$ https://hudoc.exec.coe.int/eng\#\{\%22tabview\%22:[\%22document\%22],\%22EXECIdentifier\%22:[\%22DH-DD(2019)250E\%22]] > (accessed, on 22 August, 2021).

39 On the other amendments in the Turkish Constitution, please see $<$ http://anayasadegisikligi.barobirlik.org.tr/Anayasa_Degisikligi.aspx $>$ (accessed, on 10 September, 2021).

40 GÖZLER, Kemal, “Askeri Yargı Organlarının Avrupa İnsan Hakları Sözleşmesine Uygunluğu Sorunu”, İnsan Hakları Y1llığı, Volume 21-22, 1999-2000, p. 77-80. 
Differently, the abolition of local norms can also change domestic case-law. In this vein, for example, Turkish authorities seized the book of Ömer Şükrü Asan - Pontus Kültürü - upon a decision of the night judge to whom Istanbul State Security Court in 2002 requested for a decision to seize the book, without an examination or investigation, on the basis of a variety of local norms including additional Article 1/2 of the Press Law No. 5680. For the Istanbul State Security Court, the book had made separatist propaganda in an attempt to influence those who were attracted by Pontus culture in and around Trabzon. The Court stated, nonetheless, that the order concerned gave rise to a breach of Article 10 of the Convention - the right to freedom of expression - since it partially censored the activities of writers and journalists and greatly limited their ability to express their views and criticize. ${ }^{41}$ To prevent similar violations, the Turkish authorities took general measures ${ }^{42}$, according to the action report prepared for this case, dated 21 June 2018. First of all, Press Law No. 5680, which was in effect when the book was seized, was replaced by Press Law No. 5187.

Compared with the old Press Law, the current Press Law introduces circumstances for the seizure of the published materials. To seize printed works, a judge's order and investigation process are required with respect to the offences set forth in the Article of the Press Law No. 5187. Apart from this, the Law on the Amendment on Certain Laws for Accelerating Judicial Services and the Suspension of Trial and Punishment Relating to Crimes Committed through Press also introduced some significant provisions in respect to the seizure of published studies, entering into force in 2012. Pursuant to this subsequent amendment, ordering the seizure of future periodical publications is no longer possible. The abolition of the related local norms brought about the change of domestic decisions. In this regard, for instance, the request given to İzmir Magistrates' Judgeship for the suspension of the books authored by the journalist Can Dündar and of his documentary, Mustafa, was denied, since no investigation had been

\footnotetext{
41 Asan v. Türkiye [Second Section], no. 28582/02, 27 November 2007.

42 "Communication from Turkey concerning the case of ASAN v. Turkey", <https://hudoc.exec.coe.int/eng\#\{\%22tabview\%22:[\%22document\%22],\%22EXECIdentifier\%22:[\%22DH-DD(2018)664E\%22]] (accessed, on 17 June, 2021).
} 
conducted against the works concerned ${ }^{43}$, which, in fact, is in line with the Court's findings, as well as the new Press Law. Therefore, this change in Turkish municipal law indicated the alignment of domestic courts' decisions and practices with the Court's findings.

\subsection{The Amendments of Norms}

This section is devoted to the examination of the amendments of norms in Turkey. In the amendments of norms, the norm, which the Court rules it to be a breach of the Convention, is amended in accordance with the final judgment. In this regard, for instance, Turkey breached the applicants' right to freedom of expression under the Engin Group of Cases consisting of eight cases examined by the Court, some of which would also concern the violation of the right to a fair trial. ${ }^{44}$ In the case Ergin $v$. Turkey ${ }^{45}$, the applicant, Ahmet Ergin, who was the editor of the newspaper - Günlük Emek, was sentenced to imprisonment of two-month and was imposed a heavy fine, on the grounds of Article 155 of Criminal Code Law no. 765 replaced with Turkish Criminal Code no. 5237, due to an article in that newspaper written by Barış Avşar and which, according to the public prosecutor who served at the Military Court of the General Staff at the time, incited Turkish people to evade military service. The said article, which the Court found it to be a violation of the Convention, provides that "it shall be an offence, punishable by two months to two years' imprisonment and a fine ... to public articles inciting the population to break the law or weakening national security, to issue publications intended to incite other to evade military service...". ${ }^{46}$ Accordingly, Turkey took both individual and general measures to abide by all final judgments in these cases to which it was a party. In terms of general measures, Turkey opted for the legislative amendments. The relevant article was amended in Turkish Criminal Code no. 5237 in 2013. According to the action report for the group of cases, the Committee of Minister observed

43 Ibid. p. 2-4.

44 "Communication from Turkey concerning the ERGIN (No. 6) group of cases v. Turkey", <https://hudoc.exec.coe.int/eng\#\{\%22tabview\%22:[\%22document\%22],\%22EXECIdentifier\%22:[\%22DH-DD(2019)359revE\%22]\}>,(accessed, on 9 August, 2021).

45 Ergin v. Turkey [Fourth Section], no. 47533/99, 4 May 2006, para. 6-15.

$46 \quad$ Ergin v. Turkey, para. 16. 
that the aforementioned provision provided a general definition for those who would be accused of the offence in question. Nevertheless, the new provision provides that "the one who provoke those who are doing military service to immediate desertion" or "the one who incite those who would attend the military to abstain from it" 47 will face the charge. Therefore, particular conditions with the introduction of the new version of the provision were required.

On the other hand, the underlying problem causing the violation of the Convention is the domestic courts' practice rather than particular legislation, as in the cases mentioned above. In this circumstance, the amendment of a certain norm can give rise to a change in the domestic courts' practices. For instance, in this case, Saygılı and Bilgiç, the applicant Saygılı was the owner of a daily newspaper, Yeni Evrensel. After having been ceased for one-month publication, the newspaper was closed by its owner in 2001 on account of the fact that the First Chamber of the Istanbul State Security Court found the newspaper's editor-in-chief - Bülent Falakaoğlu - guilty on the basis of articles published therein which were incompatible with the Press Act Law no 5680, which read as follows:

Where offences [prescribed in Article $312 \S 2$ of the Penal Code] ... and those threatening national security and general morals are committed via the press, the relevant publication may be ordered to be shut down by the competent court for a period of three days to one month. Any publication which manifestly succeeds a previous publication that was so ordered ... shall be seized by a warrant to be issued by a magistrates' court ${ }^{49}$

Thereafter, he launched a new daily newspaper, Günlük Evrensel, of which the editor-in-chief was the applicant Saygili. After a short period of time, the Zeytinburnu Magistrates' Court issued a seizure warrant for Yeni Evrensel on the ground that Günlük Evrensel is the successor of the former newspaper. In addition, the applicants claimed that the seizure decision was not properly reasoned or justified by the court concerned,

47 "Communication from Turkey concerning the ERGIN (No. 6) group of cases v. Turkey", <https://hudoc.exec.coe.int/eng\#\{\%22tabview\%22:[\%22document\%22],\%22EXECIdentifier\%22:[\%22DH-DD(2019)359revE\%22]]>,(accessed, on 9 August, 2021).

48 Saygilı and Bilgiç v. Turkey [Second Section], no. 33667/05, 20 May 2010, para. 5-14.

$49 \quad$ Ibid. para. 15. 
lodging an application against Turkey on the breach of the violation of right to freedom of expression. The Court, in this case, held that the seizure order for the latter newspaper was not adequately examined, thus finding a breach of the Convention. As a result, Turkey took general measures, including the amendment and change in the case-law of Criminal Courts. Concordantly, the Turkish authorities amended seizure law. Article $128 \S 1$ of the Code of Criminal Procedure Law no 5271 requires concrete evidence for the competent domestic courts to render a seizure warrant. Besides that, in order to seize printed works for the offences listed, a judge's order and an inquiry process are required.

Accordingly, with this amendment, approaches of the first instance courts changed significantly. In this vein, for instance, the 2nd Chamber of the Bursa Criminal Court of General Jurisdiction, in its decision on 16 March 2016, dismissed the suspension and seizure of a newspaper. Drawing upon the case-law of the European Court and the Court of Cassation about the offence of defamation via the press, the domestic court's judgment was led to the conclusion that the criticism towards politicians in the concrete event could not be recognised as an offence of defamation, which also in line with the aforementioned amendment. ${ }^{50}$

\subsection{Passing New Norms}

When compared to the first two classifications, it refers to norms that have not been found in the legal system until then but should be included to observe the Court's final decision. In this sense, there are some significant norms ${ }^{51}$ in Turkish law that are put into effect after the Court found a breach of the Convention for particular issues. For instance, the Court ruled in the case Ümmühan Kaplan v. Turkey ${ }^{52}$ that the applicant's

50 Communication from Turkey concerning the case of SAYGILI AND BILGIC v. Turkey, <https://hudoc.exec.coe.int/eng\#\{\%22tabview\%22:[\%22document\%22],\%22EXECIdentifier\%22:[\%22DH-DD(2018)671E\%22]]> (accessed, on 26 August, 2021).

51 In this case, the individual application before the Constitutional Court, which entered into force in 2012, and reopening of cases following judgments of the Court for some particular issues can be assessed within this context as well.

52 Ümmühan Kaplan v. Türkiye [Second Section], no. 24240/07, 20 March 2012, para. 42-51. 
right to a fair trial was infringed by the respondent State. ${ }^{53}$ Since the right in question was violated, to a greater extent, for a long time and it gave rise to both systematic and structural problems in the Turkish legal system $^{54}$, the Court implemented the pilot judgment procedure in the case concerned, meaning that measures in domestic policy are promptly required to satisfy the final judgment and put an end to a common dysfunction at the national level, which would eventually bring repetitive cases before the European Court with regards to the right to a fair trial.

Turkey passed new norms on the settlement of some applications filed before the Strasburg Court via payment of compensation on 9 January 2013. As a consequence, the Human Rights Compensation Commission (hereafter the HRCC') was established under Law no 6384 in the same year as a domestic remedy, which the Court found it as effective and sufficient to bring the related violations to an end in the case Müdür Turgut ve Diğerleri v. Turkey. ${ }^{55}$

Because of the importance of the matter, the question of how the HRCC functions would allow us to grasp better the Court's impact on the local norm. The Commission was comprised of five judges with the aim of settling applications via payment of compensation. The jurisdiction of the HRCC cover applications made to the Court before 23 September 2012 concerning investigation and prosecution under criminal law, and proceedings under private and administrative law where hearings could not be concluded with a reasonable time or that are executed late or incompletely. When an application to the Commission carries form and procedure requirements, it is subjected to a preliminary examination by the

53 SEKMEN, Murat, “6384 Sayılı Kanun ile Kurulmuş İnsan Hakları Tazminat Komisyonu", Uluslararası Hukuk Bülteni,Volume 7, 2016, p. 7.

54 The justifications put forward by the government in the draft law for the related settlement were extremely similar to the Court's rulings for the relevant case. The Turkish authorities, on the one hand, stated that the number of applications lodged against Turkey before the Court reached at 15,940 at the end of the year 2012 and almost 2500 of them fell under the scope of the right to a fair trial. The government, moreover, also took into account the necessity of a national remedy for providing redress to applicants, marking the principle of subsidiarity. Please see $<$ https://www2.tbmm.gov.tr/d24/1/1-0625.pdf>, (accessed, on 05 September, 2021).

55 Müdür Turgut ve diğerleri v. Türkiye [Second Section], no. 4860/09, 26 March 2013, para. $43-47$. 
HRCC. After this, the compensation Commission renders a compensation decision, considering the Convention, the case-law of the Court, and its Additional Protocols to which Turkey became a party. ${ }^{56}$

It remains to be mentioned here that if the compensation to be awarded by the HRCC is less than the compensation given in similar cases in the Turkish legal system, which indeed results in an infringement of the Convention, according to the Court's interpretation. ${ }^{57}$ However, it is also noteworthy that the amount of compensation can vary, depending on the nature and the effectiveness of domestic remedies and that the compensation to be awarded should be in accordance with the living standards, as well as the domestic legal tradition of the country. ${ }^{58} \mathrm{But}$, the Court also held on the effectiveness and sufficientness of the HRCC that it is capable of providing a reasonable compensation and redressing possible violations. ${ }^{59}$

If the applicant does not accept the amount of compensation awarded by the Commission, he or she can make an appeal to Ankara Regional Administrative Court (hereafter the ARAC) within fifteen days that starts with the notification of the Commission's judgment to the applicant. ${ }^{60}$ Secondly, the applicant can also make an application before the Turkish Constitutional Court, if her or she find the decision rendered by the ARAC to be insufficient; otherwise, the ARAC's decision becomes. Lastly, the applicant is not satisfied before the Constitutional Court, he or she has the right to file an application to the Strasburg Court.

\section{CONCLUSION}

This article revolves neatly around the issue of how the Strasburg Court affects local norms of Parties to the Convention. To this end, the manuscript has attempted to understand the impact of the Court over local norms within the example of Turkey. The case study presented here

\footnotetext{
56 Avrupa İnsan Hakları Mahkemesine Yapılmış Bazı Başvuruların Tazminat Ödenmek Suretiyle Çözümüne Dair Kanun, No. 6384, 19 January 2013, [hereafter, the Law no 6384].

57 Vidakovic v. Serbia [Second Section], no. 16231/07, 24 May 2011, para. 31.

58 Cocchiarella v. Italy [GC], no. 64886/01, 29 March 2006, para. 97.

59 Erol v. Türkiye [First Section], no. 76290/13, 06 May 2014, para. 18.

60 The Law No 6384, art. 7.
} 
provides a good example of how a human rights court may affect the transformation, evolution and abolition of local norms. From another perspective, the case of Turkey also offers insights into how an international court may influence domestic norms in a decisive way. As discussed throughout this paper, the Court, due to the very nature of the Convention itself, is able to affect local norms of state parties. Nevertheless, the impact of the Court on domestic norms of a national law needs to be addressed since it stays silent its influence on local norms of member states, by and large. Within the context of the case study examined in this study, the Court is capable of abolishing and amending local norms of Turkey on the one hand. On the former, domestic norms in the respondent States could be in conflict with the Court's final decision, which would require the abolition of the related norms. In such a case, the state parties concerned are under the obligation the take necessary measures in an effort to both provide redress to the applicant and comply with the Convention. As discussed previously, the legal practice of the SMAC and norms regulating it were completely removed from the Turkish legal order, with the adoption of the Law on Amendment of the Constitution of the Republic of Turkey. Moreover, the abolition of local norms can change domestic case-law as well, as in the case Asan v. Türkiye where İzmir Magistrates' Judgeship, on the ground of the current Press Law, declined the request for the suspension of the books. As to the latter, legislative amendments in the case of Turkey, such as the amendment of Article 155 of Criminal Code Law no. 765, brought some alterations, all of which are in line with the final judgment of the Strasbourg Court. With the amendment, a general definition for those who would be accused of the offence in question was provided. This amendment also brought about a change in the domestic case law. On the other, the Court also may leave Turkey to choose to pass new norms in accordance with the ruling of the Court, which sometimes may establish new domestic remedies, as in the case of the HRCC, which need to be exhausted before submitting an application to the Court. In this context, it is worth mentioning that proceedings before the commission is awfully similar to that of the European Court in many aspects, as is evidently demonstrated. Lastly, except for passing new norms, the abolition and amendment of local norms of Turkey also 
The Impact of The European Court of Human Rights over Local Norms ... 3319 brought about the change of domestic case-law, thanks to new local norms made according to the final judgment of the Court. 


\section{BIBLIOGRAPHY}

ABDELGAWAD, Elisabeth Lambert, The Execution of Judgments of the European Court of Human Rights, Council of Europe Publishing, Strasbourg 2008.

APAYDIN, Deniz Tekin, “Monizm-Dualizm İkileminde Türk Hukuk Sistemi: Uluslararası Hukuka Bakış Üzerine Doktrinel Uzlaşmazlığın Nedenleri ve AB Hukuku Işığında Bir Değerlendirme", İnönü Üniversitesi Hukuk Fakültesi Dergisi, Volume 9, No 1, 2018 (pp. 529-560).

AYBAY, Rona, “Uluslararası Antlaşmaların Türk Hukukundaki Yeri”, Türkiye Barolar Birliği Dergisi, Volume 70, 2007 (pp. 187-213).

BİLGİN, Ahmet Burak, “Avrupa İnsan Hakları Sözleşmesinin İç Hukuktaki Yeri", Marmara Üniversitesi Hukuk Fakültesi Hukuk Araştırmaları Dergisi, Volume 22, No 1, 2016 (pp. 81-129).

BOND, Martyn, An Introduction to the European Convention on Human Rights, Council of Europe Publishing, Strasbourg 2018.

CAN, Hacı, "Türk Hukuk Düzeninin Milletlerarası Hukuka Açıklığı", Yasama Dergisi, Volume 12, No 5, 2009 (pp. 5-65).

Communication from Turkey concerning the case of ASAN v. Turkey, https://hudoc.exec.coe.int/eng\#\{\%22tabview\%22:[\%22document\%22],\%22EXECIdentifier\%22:[\%22DH-DD(2018)664E\%22]\} (accessed, on 17 June, 2021).

Communication from Turkey concerning the case of SAYGILI AND BILGIC v. Turkey, <https://hudoc.exec.coe.int/eng\#\{\%22tabview\%22:[\%22document $\% 22]$,\%22EXECIdentifier\%22:[\%22DHDD(2018)671E\%22]\} (accessed, on 26 August, 2021).

Communication from Turkey concerning the ERGIN (No. 6) group of cases v. Turkey, https://hudoc.exec.coe.int/eng\#\{\%22tabview\%22:[\%22document\%22],\%22EXECIdentifier\%22:[\%22DHDD(2019)359revE\%22]\} (accessed, on 9 August, 2021).

Communication from Turkey concerning the Esim group of cases v. Turkey, 
https://hudoc.exec.coe.int/eng\#\{\%22tabview\%22:[\%22document\%22],\%22EXECIdentifier\%22:[\%22DH-DD(2019)250E\%22]\} (accessed, on 22 August, 2021).

DZEHTSIAROU, Kanstantsin/ TZEVELEKOS, Vassilis P., "The Conscience of Europe that Landed in Strasbourg: A Circle of Life of the European Court of Human Rights", European Convention on Human Rights Law Review, no 1, (2020): 1-6.

GÖZLER, Kemal, “Askeri Yarg1 Organlarının Avrupa İnsan Hakları Sözleşmesine Uygunluğu Sorunu", İnsan Hakları Yıllığı, Volume 21-22, 1999-2000 (pp. 77-93).

GÖZTEPE, Ece, “Avrupa İnsan Hakları Mahkemesi Kararlarının İç Hukuka Etkisi Sorunu: Federal Alman Anayasa Mahkemesi'nin İki Kararının Bir Değerlendirilmesi", within Erdoğan Teziç'e Armağan, (pp. 417-429). Galatasaray Üniversitesi Yayınları, Istanbul 2007.

İNCEOĞLU, Sibel, "Hak ve Özgürlükleri Sınırlama ve Güvence Rejimi”, Within İnsan Hakları Avrupa Sözleşmesi ve Anayasa: Anayasa Mahkemesine Bireysel Başvuru Kapsamında Bir İnceleme, editor Sibel İnceoğlu, (pp. 23-53). Beta Yayınları, Istanbul 2013.

ISSAEVA Maria/ SERGEEVA, Irina/ SUCHKOVA, Maria, “Enforcement of the Judgments of the European Court of Human Rights in Russia", International Journal on Human Rights, Volume 8, No 15, 2011 (pp. 66-89).

SAĞLAM, Fazıl, “Avrupa İnsan Hakları Mahkemesi'nin Türkiye'de Kapatılan Partilere İlişkin Kararlarının Partiler Hukukuna Etkisi”, pp. 189-216, https://ayam.anayasa.gov.tr/media/6307/fazil_saglam.pdf, (accessed, on 21 November, 2021).

MOORHEAD, Timothy, "European Union Law as International Law", European Journal of Legal Studies, Volume 5, No 1, 2012 (pp. 126-143).

PAZARCI, Hüseyin. Uluslararası Hukuk, Ankara: Turhan Kitapevi, 2009.

QORABOYEV, Ikboljon and Emre Turkut, "Turkey”, Within Duelling for Supremacy: International Law vs. National Fundamental 
Principles, editor Fulvio Maria Palombino, ( pp. 336-354), Cambridge University Press, Cambridge 2019.

SALİHPAŞAOĞLU, Yaşar, “Avrupa İnsan Hakları Mahkemesi ve Türkiye: Bazı Rakamlar ve Gerçekler", Gazi Üniversitesi Hukuk Fakültesi Dergisi, Volume 8, No 1-2, 2009 (pp. 253-281).

SEKMEN, Murat, "6384 Sayılı Kanun ile Kurulmuş İnsan Hakları Tazminat Komisyonu." Uluslararası Hukuk Bülteni, Volume 7, 2016 (pp. 7-9).

WASSENBERG, Birte, History of the Council of Europe, Council of European Publishing, Strasbourg 2013.

http://anayasadegisikligi.barobirlik.org.tr/Anayasa_Degisikligi.aspx (accessed, on 10 September, 2021).

https://www.coe.int/en/web/portal/home

https://www.global.tbmm.gov.tr/ (accessed, on 27 November, 2021).

https://www2.tbmm.gov.tr (accessed, on 05 September, 2021).

\section{The Judgments of the European Court of Human Rights}

Aleksanyan v. Russia [First Section], no. 46468/06, 22 December 2008.

Asan v. Türkiye [Second Section], no. 28582/02, 27 November 2007.

Assanidze v. Georgia [GC], no. 71503/01, 8 April 2004.

Cocchiarella v. Italy [GC], no. 64886/01, 29 March 2006.

Del Rio Prada v. Spain [GC], no. 42750/09, 21 October 2013.

Ergin v. Turkey [Fourth Section], no. 47533/99, 4 May 2006.

Erol v. Türkiye [First Section], no. 76290/13, 06 May 2014.

Esim v. Turkey [Second Section], no. 59601/09, 17 September 2013.

Gasangusenov v. Russia [Third Section], no. 78019/17, 30 March 2021.

Georgia v. Russia (II) [GC], no. 38263/08, 21 January 2021.

Kastmakhunov and Saybatalov v. Russia [First Section], nos. 26261/05 and 26377/06, 14 March 2013.

Marckx v. Belgium [Plenary], no. 6833/74, 13 June 1979. 
Müdür Turgut ve diğerleri v. Türkiye [Second Section], no. 4860/09, 26 March 2013.

N.D. and N.T. v. Spain [GC], nos. 8675/15 and 8697/15, 13 February 2020. Öcalan v. Turkey [GC], no. 46221/99, 12 May 2005.

Saygilı and Bilgiç v. Turkey [Second Section], no. 33667/05, 20 May 2010. Sefer Yılmaz ve Meryem Y1lmaz / Türkiye [Second Section], no. 611/12, 17 November 2015.

Soering v. The United Kingdom [Plenary], no. 14038/88, 07 June 1989.

Ümmühan Kaplan v. Türkiye [Second Section], no. 24240/07, 20 March 2012.

Vidakovic v. Serbia [Second Section], no. 16231/07, 24 May 2011. 